\begin{tabular}{|l|l|l||}
\hline \multicolumn{2}{|c|}{ PublisherInfo } \\
\hline \hline PublisherName & $:$ & BioMed Central \\
\hline \hline PublisherLocation & $:$ & London \\
\hline \hline PublisherImprintName & $:$ & BioMed Central \\
\hline \hline
\end{tabular}

\title{
Minding the genome gap
}

\begin{tabular}{|l|l|l||}
\hline \multicolumn{2}{|c|}{ ArticleInfo } \\
\hline \hline ArticleID & $:$ & 4933 \\
\hline \hline ArticleDOI & $:$ & $10.1186 /$ gb-spotlight-20040406-01 \\
\hline \hline ArticleCitationID & $:$ & spotlight-20040405-01 \\
\hline \hline ArticleSequenceNumber & $:$ & 285 \\
\hline \hline ArticleCategory & $:$ & Research news \\
\hline ArticleFirstPage & $:$ & 1 \\
\hline \hline ArticleLastPage & $:$ & 3 \\
\hline \hline & & RegistrationDate : 2004-4-6 \\
\hline ArticleHistory & $:$ & OnlineDate \\
\hline \hline ArticleCopyright & $:$ & BioMed Central Ltd2004-4-6 \\
\hline \hline ArticleGrants & $:$ & \\
\hline \hline ArticleContext & $:$ & 130594411 \\
\hline \hline
\end{tabular}




\section{Stephen Pincock}

Email: Stephen@thescientisteurope.com

BERLIN - Roughly a year after the human genome sequence was completed, scientists meeting at the opening of the Human Genome Meeting on Sunday (April 4) were reminded about the enormous gaps that remain in our understanding of our genetic makeup.

"We have the sequence of 100 species or so a click away on the Web... but how do we use that information? How can we address the complexity of disease background at the DNA level?" asked Leena Peltonen, from the University of Helsinki in Finland. "We shouldn't be unrealistically optimistic."

"We are still not sure what is the best way to understand the function of the genome," Human Genome Organisation (HUGO) President Yoshiyuki Sakaki told the opening session. Maynard Olson from the University of Washington, added, "The future of genomics is a really big topic."

Olson said that future may be in peril unless the scientific establishment focuses on a fundamental aspect of human genetics that has been overlooked: how the most obvious differences among individuals - like hair color, height, weight, and handedness - are generated.

"It's truly striking... how little we know about these obvious questions that even a child would ask," Olson said. "Why have geneticists ignored this question of why humans vary from one another in these ways?" he asked. It has been ignored partly because of the complexity of the issue, the difficulty of getting funds for nonmedical research, and "the long shadow of eugenics," Olson said. "Our obsessive focus on disease genotypes is premature... My broader agenda is essential for longer-term benefits."

"It's going to take all of our efforts... to develop the level of trust with society that would make it acceptable to study this subject that is essential to human genomics," Olson said. Difficult as these ethical issues are, mainstream science needs to focus on them, rather than leave it to rogue elements, he said. "Are we prepared to bring to bear the value systems of the science establishment on these questions or are we going to engage in a long guerrilla war with fringe elements?" he asked.

\section{References}

1. Powledge TM: Human Genome Project completed Genome Biology, April 15, 2003., [http://genomebiology.com/researchnews/default.asp?arx_id=gb-spotlight-20030415-01] 
2. Human Genome Meeting, Berlin, April 4-7, 2004, [http://hgm2004.hgu.mrc.ac.uk/]

3. Leena Peltonen, [http://www.hi.helsinki.fi/hi/res/palotie/palotie.html]

4. Yoshiyuki Sakaki, [http://www.hgc.ims.u-tokyo.ac.jp/organize/sakaki/members/sakaki/]

5. Maynard Olson, [http://www.gs.washington.edu/faculty/olson.htm] 